\section{Acetylcholinesterase in Thrombocytes}

IT has been shown recently ${ }^{1}$ that the thrombocytes of rat blood contain a cholinesterase having properties similar to the acetylcholinesterase found in erythrocytes. The present communication gives evidence for the presence of an acetylcholinesterase in the thrombocytes of other animals.

The thrombocytes were isolated from the blood of different animals ${ }^{1}$, washed twice in saline solution, and then suspended in a suitable volume of distilled water. The cholinesterase activity of these suspensions was determined manometrically in the Warburg apparatus with acetylcholine and butyrylcholine as substrates. The results are recorded in the accompanying table.

HYDROLYSIS OF ACETYLCHOIIINE AND BUTYRYLCHOLINE BY Esterase activity $\left(b_{30}\right)$ expressed in $\mu \mathrm{l}$.

a preparation and $1.6 \mathrm{ml}$. of the substrate solution. Citrate blood

\begin{tabular}{|c|c|c|c|}
\hline \multirow[b]{2}{*}{ Animal } & \multicolumn{2}{|c|}{$b_{30}$} & \multirow{2}{*}{$\begin{array}{c}b_{30} \\
\text { acetylcholine } \\
\text { per } 100 \mathrm{mgm} \text {. } \\
\text { dry weight }\end{array}$} \\
\hline & $\begin{array}{c}\text { acetylcholine } \\
3 \cdot 30 \times 16^{-3} M\end{array}$ & $\begin{array}{l}\text { butyrylcholine } \\
9.54 \times 16^{-4} M\end{array}$ & \\
\hline Rat $\sigma$ & $89 \cdot 5$ & 18 & 9,320 \\
\hline $\begin{array}{l}\text { Rat } \delta \\
\text { (citrate blood) }\end{array}$ & 52 & $11 \cdot 5$ & 一 \\
\hline Rat ? & $98 \cdot 5$ & 4 & 10,250 \\
\hline Rabbit & $\begin{array}{r}225 \\
66\end{array}$ & $\begin{array}{r}4 \cdot 5 \\
14 \cdot 5\end{array}$ & $\begin{array}{l}22,800 \\
17,000\end{array}$ \\
\hline Dog & $54 \cdot 5$ & $16 \cdot 5$ & 3,630 \\
\hline Horse & 91 & 3 & 9,100 \\
\hline
\end{tabular}

Cat and rabbit thrombocytes show a significantly higher esterase activity than rat thrombocytes. Acetylcholine is split at a much higher rate than butyrylcholine. This is one of the characteristics of an acetylcholinesterase, that is, the type of acetylcholine-splitting enzymes known to occur chiefly in nervous tissues, electric organs, and erythrocytes ${ }^{2}$.

A further characteristic feature of acetylcholinesterase is that its activity is depressed when the acetylcholine concentration is higher than $3 \times 10^{-3} \mathrm{M}$. The relationship between the esterase activity of thrombocytes and acetylcholine concentration is shown in the accompanying graph (upper curve). An almost symmetrical bell-shaped curve is obtained when the esterase activity is plotted against the negative logarithm of the substrate concentration $(p S)$. The optimum acetylcholine concentration is the same for all thrombocyte preparations studied and corresponds to that found for the acetylcholinesterase from other sources ${ }^{2}$. The lower curve in the graph shows that choline inhibits the activity and the optimum substrate concentration is shifted to a higher level.

Tributyrin and benzoylcholine are not hydrolysed; but acetyl- $\beta$-methylcholine is split at a relatively high rate. Specific inhibitors of acetylcholinesplitting enzymes also inhibit the thrombocyte esterase. Thus, for example, the $I_{50}$ value (molar inhibitor concentration giving 50 per cent inhibition) for tetraethylpyrophosphate (TEPP) is $5 \cdot 2 \times 10^{-9} M$ and for dimethylamido-ethoxy-phosphoryl cyanide (Tabun) $2.0 \times 10^{-9} M$. The corresponding values for the acetylcholinesterase from human erythrocytes are $3.2 \times 10^{-8} M$ and $3.95 \times 10^{-9} M$ respectively.

The results show that the thrombocytes of different animals contain a cholinesterase and that this esterase is an acetylcholinesterase (acetocholinesterase, "specific" cholinesterase), known to be

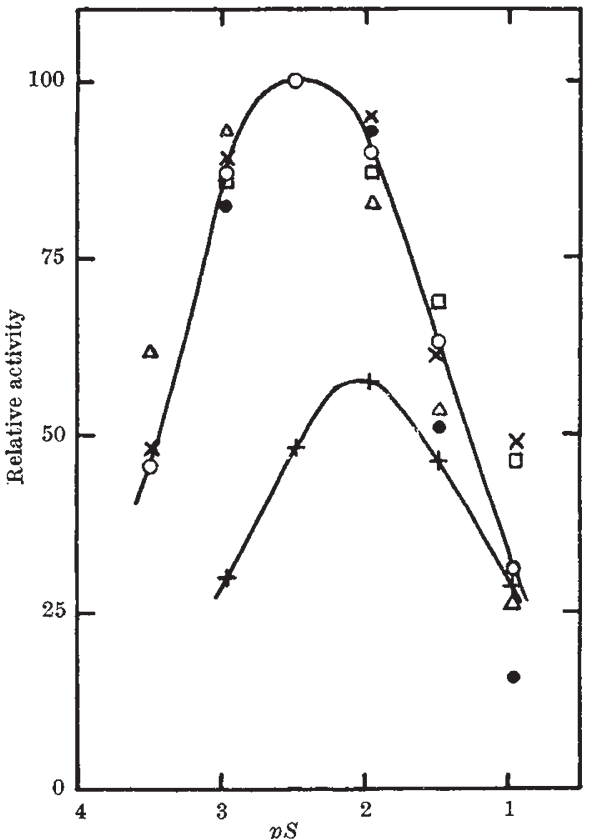

Activity $p S$ curves for the thrombocyte acetylcholinesterase of different animals. Substrate : acetylcholine chloride. $O$, cat ; , rat ; $\times$, rabbit ; $\square$, dog; $\triangle$, horse ; + , cat throm

present in the erythrocytes of most animals. It is pertinent to mention that several authors ${ }^{3-5}$ have described the presence of such an esterase also in the plasma of certain animals. We would like to suggest tentatively that thrombocytes may be one of the probable sources of this enzyme in the plasma.

Klas-Bertil Augustinsson

Nirmal DATTA

Margareta GrahN

JOSEPH ZAJIČEK

Institute of Organic Chemistry

and Biochemistry,

University of Stockholm, and

Cancer Research Division,

Fadiumhemmet, Stockholm. Dec. 1.

${ }^{1}$ Zajiček, J., and Datta, N., Acta Hamaiol., 7, 39 (195\%).

"Augustinsson, K.-B., in "The Enzymes" (Sumner-Miyrbäck), 1, Pt. 1 , 143 (Academic Press, New York, 1950).

${ }^{3}$ Mendel, B, and Rudney, H., Biochem. J., 37, 59 (1943).

'Levine, M. G., Hoyt, R. E., and Suran, A. A., Proc. Soc. Exp. Biol.

${ }^{5}$ Lévy, J., J. Physiol., 43, 103, 127, 217,229 (1951).

\section{Identification of Enteramine, the Specific Hormone of the Enterochromaffin Cell System, as 5 -Hydroxytryptamine}

ENTERAMINE is the specific secretion or storage product of the typical enterochromaffin cells of the gastrointestinal mucosa of Vertebrata and Ascidia (hence the name 'enteramine'), of the chromaffin cellular elements of the posterior salivary glands of Octopoda and of the hypobranchial body of Muricidæ, as well as of at least a part of the chromaffin granular cells of the cutaneous glands of Amphibia. In all its occurrences, enteramine appears to be identical.

Chemically speaking, the specific product of the enterochromaffin cells was considered by histologists, 